\title{
Validation of New ELISA Technique for Detection of Aflatoxin B1 Contamination in Food Products versus HPLC and VICAM
}

\author{
Elsayed Hafez ${ }^{1}\left(\mathbb{D}\right.$, Nourhan M. Abd El-Aziz ${ }^{2}$, Amira M. G. Darwish ${ }^{2} \mathbb{D}$, Mohamed G. Shehata $^{2, *(\mathbb{D})}$ \\ Amira A. Ibrahim ${ }^{1}\left(\mathbb{D}\right.$, Asmaa M. Elframawy ${ }^{3}$ and Ahmed N. Badr ${ }^{4}$ (D) \\ 1 Department of Plant Protection and Biomolecular Diagnosis, Arid Lands Cultivation Research \\ Institute (ALCRI), City of Scientific Research and Technological Applications (SRTA-City), \\ Alexandria 21934, Egypt; elsayed_hafez@yahoo.com (E.H.); amiranasreldeen@yahoo.com (A.A.I.) \\ 2 Department of Food Technology, Arid Lands Cultivation Research Institute (ALCRI), City of Scientific \\ Research and Technological Applications (SRTA-City), Alexandria 21934, Egypt; \\ nourhanm.abdo@gmail.com (N.M.A.E.-A.); amiragdarwish@yahoo.com (A.M.G.D.) \\ 3 Nucleic Acids Research Department, Genetic Engineering \& Biotechnology Research Institute (GEBRI), \\ City of Scientific Research and Technological Applications (SRTA-City), Alexandria 21934, Egypt; \\ asmaameg@yahoo.com \\ 4 Food Toxicology and Contaminants Department, National Research Centre, Dokki, Cairo 12622, Egypt; \\ noohbadr@gmail.com \\ * Correspondence: gamalsng@gmail.com
}

Citation: Hafez, E.; Abd El-Aziz, N.M.; Darwish, A.M.G.; Shehata, M.G.; Ibrahim, A.A.; Elframawy, A.M.; Badr, A.N. Validation of New ELISA Technique for Detection of Aflatoxin B1 Contamination in Food Products versus HPLC and VICAM. Toxins 2021, 13, 747. https://doi.org/ $10.3390 /$ toxins 13110747

Received: 16 July 2021

Accepted: 8 October 2021

Published: 21 October 2021

Publisher's Note: MDPI stays neutral with regard to jurisdictional claims in published maps and institutional affiliations.

\section{Copyright: (c) 2021 by the authors.} Licensee MDPI, Basel, Switzerland. This article is an open access article distributed under the terms and conditions of the Creative Commons Attribution (CC BY) license (https:// creativecommons.org/licenses/by/ $4.0 /)$.

\begin{abstract}
AbstractToxin-contaminated foods and beverages are a major source of illness, may cause death, and have a significant negative economic impact worldwide. Aflatoxin B1 (AFB1) is a potent toxin that may induce cancer after chronic low-level exposure. This study developed a quantitative recombinant $A f l R$ gene antiserum ELISA technique for aflatoxin B1 detection in contaminated food products. Aflatoxin B1 residuals from 36 food samples were analyzed with HPLC and VICAM. DNA was extracted from aflatoxin-contaminated samples and the AflR gene amplified using PCR. PCR products were purified and ligated into the pGEM-T vector. Recombinant plasmids were sequenced and transformed into competent E. coli (BL21). Molecular size and B-cell epitope prediction for the recombinant protein were assessed. The purified protein was used to induce the production of IgG antibodies in rabbits. Serum IgG was purified and labeled with alkaline phosphatase. Finally, indirect-ELISA was used to test the effectiveness of polyclonal antibodies for detection of aflatoxin B1 in food samples.
\end{abstract}

Keywords: aflatoxin B1; recombinant AflR gene; VICAM; HPLC; I-ELISA; peanut; wheat flour; milk powder

Key Contribution: The indirect-ELISA technique was compared with HPLC and the VICAM system in food samples. The new technique showed reasonable accuracy; cost- and time-effective detection of aflatoxin B1.

\section{Introduction}

Mycotoxins are toxic secondary metabolites produced naturally by many fungi under certain growth conditions. These toxins affect metabolic processes and cause disease and death in humans and animals [1]. Toxicological actions of mycotoxins are recognized but few of these compounds or their derivatives are identified as antibiotics, growth promoters, or other drugs. Major mycotoxins include aflatoxins, gliotoxin, citrinin, ergot alkaloids, fumonisins, ochratoxin, and patulin [2].

Humans do not produce antibodies to mycotoxins and cannot be immunized against their toxicity. Nearly $25 \%$ of food becomes inedible due to contamination with mycotoxins; aflatoxins are the most serious source of contamination [3]. In 1993, aflatoxin is classified as a class one carcinogen by the World Health Organization Cancer Research Institute. 
Aflatoxin causes hepatotoxicity in both humans and animals. Exposure to this toxin can lead to liver cancer and death. The chemical is a bifuran toxoid produced by strains of Aspergillus flavus and Aspergillus parasiticus. About 20 derivatives are recognized, for example, B1, B2, G1, G2, M1, and M2. Aflatoxin B1 (AFB1) is the most potent and carcinogenic [4]. Aflatoxins M1 and M2 are hydroxylated metabolites of aflatoxin B1 produced by animals and commonly exist in milk and dairy products. The toxins are not common in grains. AFB1 is detected on the surfaces of maize and peanuts.

Toxicity of and exposure to AFB1 has been extensively investigated. The toxin may result in severe disease, including carcinogenesis, mutagenesis, growth retardation, and immune suppression [5]. The aflatoxin-producing fungus, $P$. flavus, grows and produces aflatoxins on preharvest maize and on maize in storage [6]. Peanuts are also susceptible to Aspergillus infection in the field or during storage. Both maize and peanuts are rich nutrient sources for these fungi [7]. Aflatoxin-contaminated agricultural products may pose serious health risks to humans and animals and negatively affect international trade [8]. According to the Food and Drug Administration (FDA) in the USA, an acceptable aflatoxin level in food is 0 ppb.

Typically, high-performance liquid chromatography (HPLC) and liquid chromatography mass spectrometry (LC-MS) are used for quantification of aflatoxins. LC-MS/MS can detect trace levels, but some limits exist. Chemical detection is slower than spectral detection (hours vs. seconds) and tedious. Professional analysts and precise chemical instruments are required [9]. Thus, accurate, rapid, full-scale detection of AFB1 is important in assessing human health and economic impacts. Evaluating contaminated food directly for specific fungi using genes that control aflatoxin is a promising strategy [10]. Gallo et al. [11] reported such genes in the genome of aflatoxin-producing fungi. However, the authors' method required costly instruments, amplification, isolation, and quantification along with trained personnel [12]. The method is quite complex and costly for routine use. This study aimed to develop a new cost- and time-effective quantitative method using modified recombinant $A f l R$ gene antiserum enzyme-linked immunoassay (ELISA) for aflatoxin B1 detection in contaminated food products.

\section{Results and Discussion}

\subsection{The Aflatoxin B1 Detection with HPLC and VICAM}

VICAM was less sensitive than HPLC analysis for aflatoxin AFB1 detection in several samples-peanut 2, flours 2 and 3, and milk-powder 3. HPLC is widely used for the analysis of aflatoxins for sensitivity and accuracy [13] (Table 1). HPLC is an excellent quantitative method in detection of aflatoxins [14], although it requires skilled operators, extensive sample preparation, and is a high-cost equipment [15].

Table 1. HPLC and VICAM screening analysis of 36 food samples for aflatoxin detection.

\begin{tabular}{ccc}
\hline Samples & HPLC & VICAM \\
\hline Peanut 1 & +++ & +++ \\
\hline Peanut 2 & +++ & ++ \\
\hline Peanut 3 & +++ & +++ \\
\hline Flour 1 & ++ & ++ \\
\hline Flour 2 & +++ & ++ \\
\hline Flour 3 & ++ & ++ \\
\hline Milk-powder 1 & ++ & + \\
\hline Milk-powder 2 & + & +
\end{tabular}

+: refers to low aflatoxin contamination level; ++: refers to moderate aflatoxin contamination level; +++: refers to high aflatoxin contamination level. 


\subsection{Molecular Detection and SDS-PAGE}

A unique band at about 760 bp was observed in all positive samples (Figure 1A). Negative amplification was observed in flour contaminated with aflatoxin (50,75, and $100 \mathrm{mg}$ ). Amplified DNA was cloned and in vitro transcribed protein was separated on SDS-PAGE (Figure 1B). SDS-PAGE analysis revealed a protein of about $28 \mathrm{kDa}$. Molecular weight determination regarded as first characterization step of protein was further used in toxin detection.

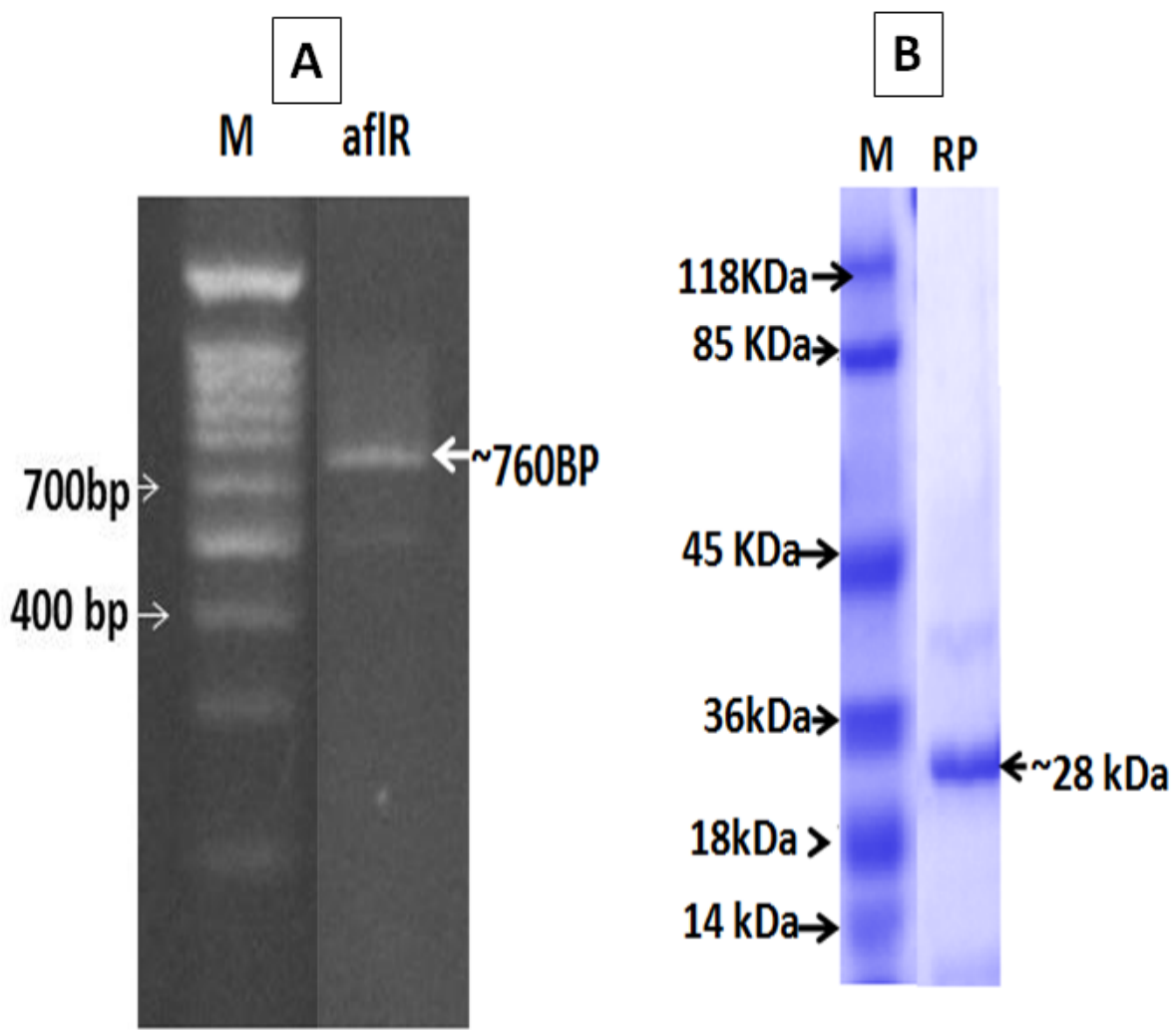

Figure 1. (A) PCR product amplified using the specific primers of the afIR gene (Aflatoxin B1). M: DNA marker and afIR the amplified gene in molecular size about $760 \mathrm{bp}$. (B) The recombinant protein of the in vitro transcribed afIR gene (Aflatoxin B1) with molecular size about $28 \mathrm{kDa}$.

\subsection{Sequence Analysis and Phylogenic Construction}

The PCR product was purified and sequenced and a $750 \mathrm{bp}$ fragment was obtained. The sequence was aligned using the NCBI analysis tool and showed $97 \%$ similarity with other AfIR genes listed in GeneBank. The sequence was compared with 50 sequences and a phylogenetic tree was constructed. An Egyptian AfIR gene was closely similar to AfIR gene MH752587 obtained from Aspergillus sp. PS-2018c isolate BN038G AFlR, Arizona, USA (Figure 2).

\subsection{Antigenicity Test}

A 256 residue amino acid sequence was deduced from the gene sequence (Table 2). Eight peptides showed antigenic activity by Kolaskar \& Tongaonkar Antigenicity [16] Figure 3. Peptide lengths ranged from 8 to 14 amino acids. Their positions started from amino acid numbers 26, 66, 107, 136, 170, 186, 205, and 236 (Table 2). Epitope prediction using Kolaskar and Tongaonkar Antigenicity Prediction identifies the protein epitopes that are useful for diagnostic purposes and also in the development of peptide vaccines [17]. 


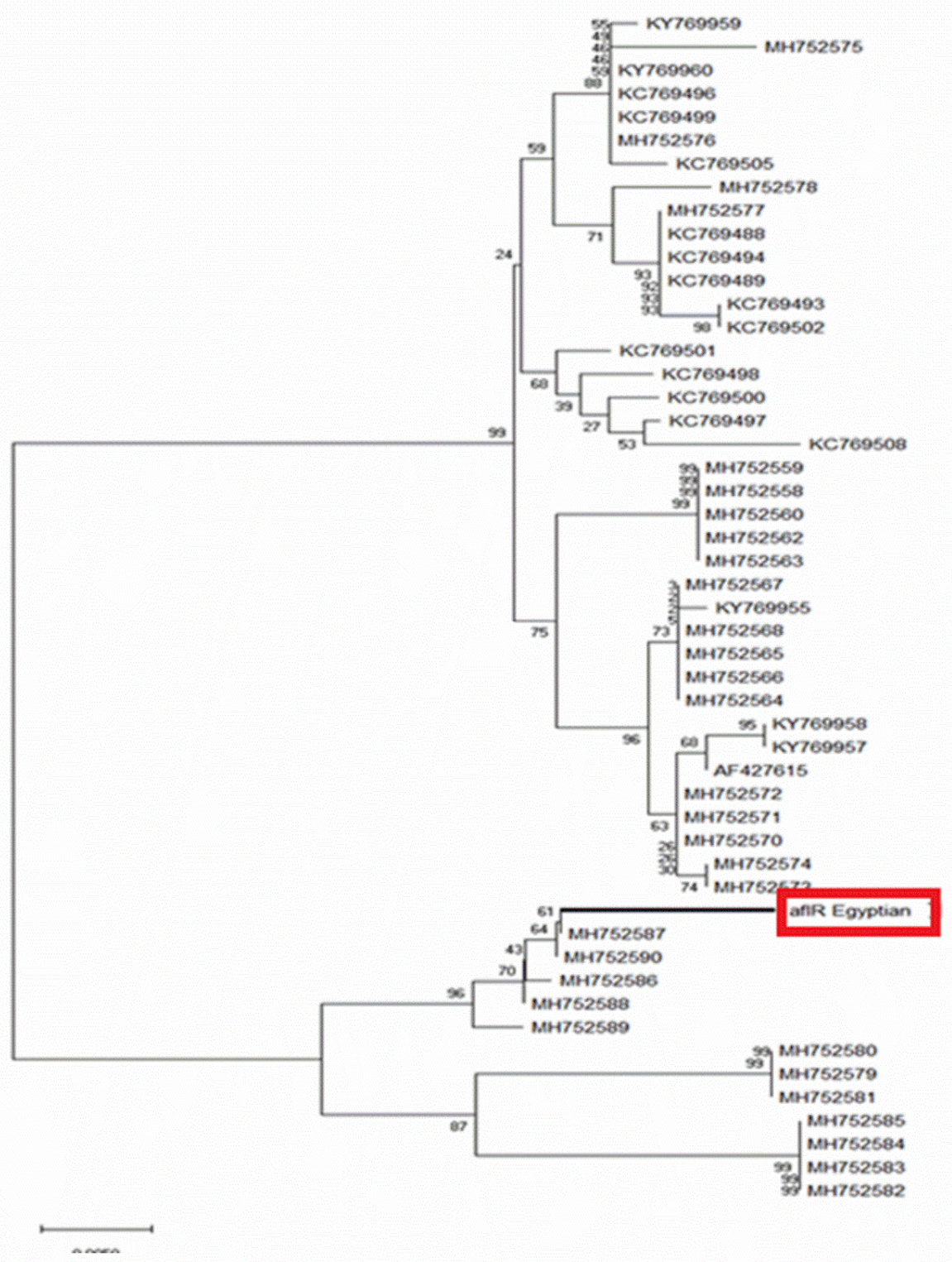

Figure 2. Phylogenetic tree for the amplified aflatoxin B1 based on the DNA nucleotide sequence and compared with the other 50 AFB1genes listed on gene bank. The phylogeny was constructed using Mega 6 program.

Table 2. Predicted peptides with antigenic activity, their length, and positions.

\begin{tabular}{cccccc}
\hline No. & Start & End & Peptide & Length & >aflIR d Deduced Amino Acid Sequence \\
\hline 1 & 26 & 33 & LMQVPKIY & 8 & MSHSYNTFAGWFINTPTGRTQGSLA LMQVPKI \\
\hline 2 & 66 & 76 & EHYLLFLVQFV & 11 & YLAGNKSFLGSQPAHDGLRYLEPEACMRAGQL \\
\hline 3 & 107 & 120 & TPQLVTFVYIHLDL & 14 & AEHYLLFLVQFV NRSRSSLVTRFQPRYVNKEC \\
\hline 4 & 136 & 143 & FTLCVPPRLA & 8 & TARQSLGQVRT PQLVTFVYIHLDL SARQRKGO \\
\hline 5 & 170 & 179 & PGRCVPPPRLA & 10 & ATLQEKAF TLCVFFPA FNSKLYSTPSSRPPRW \\
\hline 6 & 186 & 196 & IAVRVVPVQKC & 11 & LTIFPPGHI PGRCVPPRLA ALESSG IAVRVVPVQKC \\
\hline 7 & 205 & 215 & VLGVSNVVLPV & 11 & DAPRRNRP VLGVSNVVLPV NTWSPSGWAAT \\
\hline 2 & 227 & 236 & RALPVPLIQL & 10 & RALPVPLIQL GDHQRVFLQPDRNRDIRRIT \\
\hline
\end{tabular}




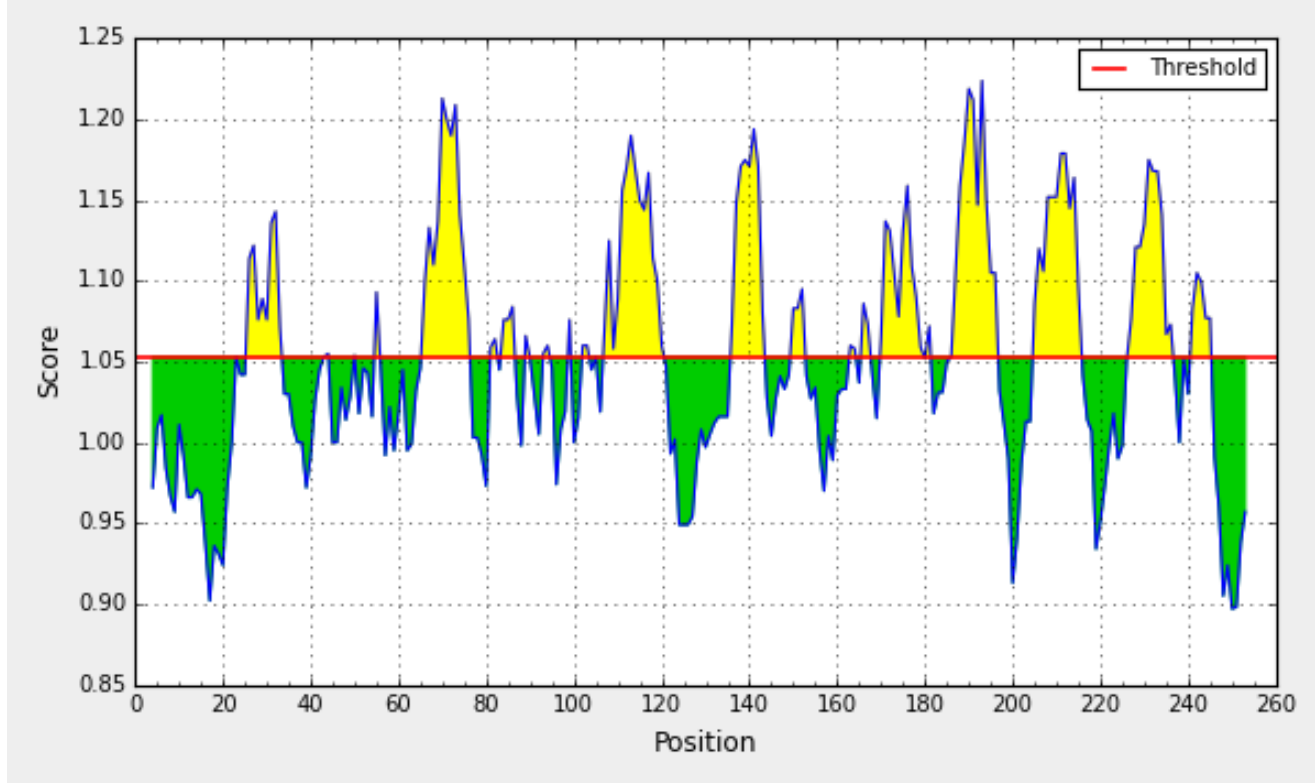

Figure 3. The predicted antigenic activity of the recombinant protein (afIR).

\subsection{IgG Polyclonal Antibody Labeling and Purification}

Serum obtained from immunized rabbits was fractionated using affinity chromatography protein G-Sepharose column and one band of conventional IgG with a molecular weight of $130 \mathrm{kDa}$ was obtained. Moreover, two bands of a $42 \mathrm{kDa}$ heavy chain and a $19 \mathrm{kDa}$ light chain were separated under reducing conditions. Glutaraldehyde was used to prepare conjugates using a ratio of 4:1 of IgG and enzyme alkaline phosphatase (AP). IgGAP conjugates were purified by gel filtration on a Sephacryl S200 column. AP (EC 3.1.3.1) is a stable enzyme its activity can be measured by many different substrates. The most common method of labeling immunoglobulin $\mathrm{G}(\mathrm{IgG})$ antibody with this enzyme uses the homobifunctional reagent glutaraldehyde [18].

\subsection{Validation of the Modified Recombinant AflR Gene Antiserum ELISA Technique with HPLC and VICAM}

In definition, validation is establishing the performance specifications of a new diagnostic tool such as a new test, laboratory developed test or modified method. But verification is defined as one-time process to determine performance characteristics of a test before use in patient testing [19].

ELISA was unable to distinguish among antigens due to the presence of common epitopes on protein surfaces [20-22]. Sampling/sub-sampling variation significantly affects the accuracy of aflatoxin analysis [23]. Extracts of 36 samples were used for validation to minimize the impacts of such variation.

Recombinant antiserum detected AfIR recombinant protein within a concentration range $0-1000 \mathrm{pg} / \mathrm{mL}$ with a linear correlation between AfIR antigenic protein and absorbance at $405 \mathrm{~nm}\left(\mathrm{y}=0.0014 \mathrm{x}-0.0148 ; \mathrm{R}^{2}=0.9946\right)$ (Figure 4$)$. Non-significant differences among three samples of the same product, peanut, flour, or milk powder, were observed after HPLC $(p>0.05)$ (Table 3$)$. The VICAM method showed similar results. However, the modified ELISA showed significant differences among toxin detections in these product samples. The serum-based analysis confirmed specific PCR results. No false negatives were observed in I-ELISA results and false positives were either nil or negligible. 


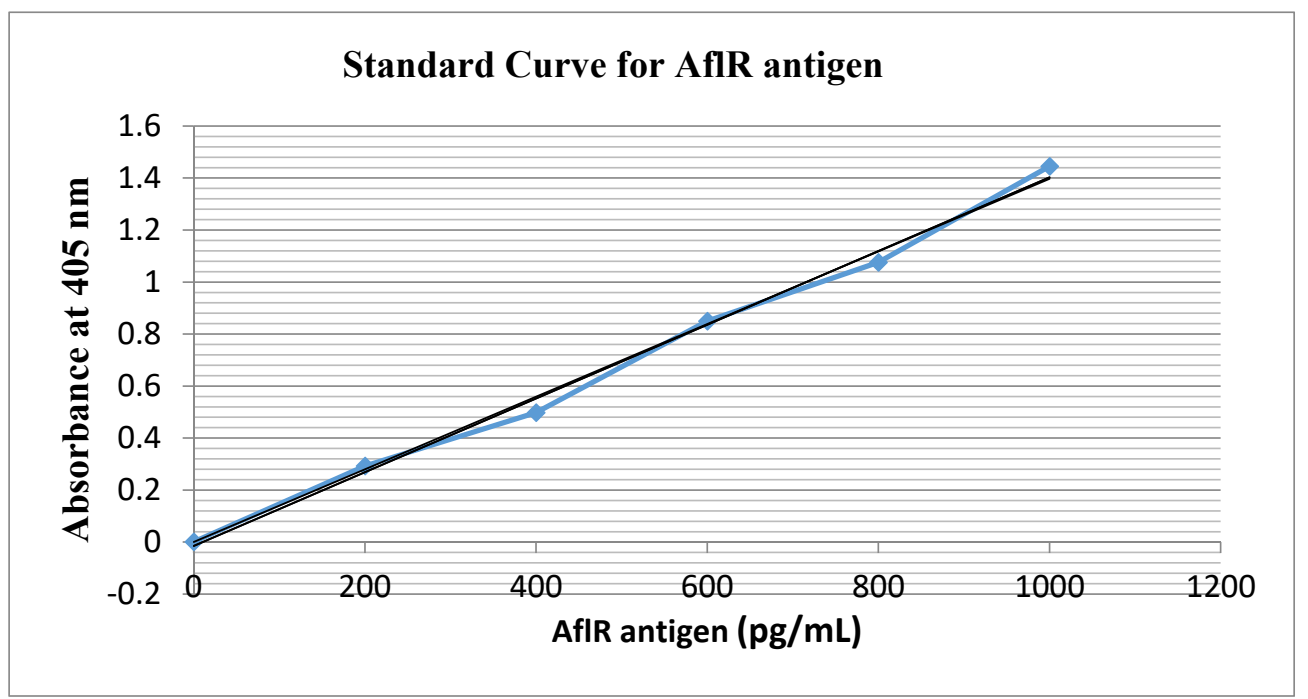

Figure 4. I-ELISA standard curve for $A f I R$ recombinant protein using purified serum IgG.

Table 3. Comparative results obtained by HPLC, VICAM, specific PCR, and I-ELISA (ng/g).

\begin{tabular}{ccccc}
\hline Sample & HPLC (ng/g) & VICAM (ng/g) & Specific PCR & $\begin{array}{c}\text { ELISA } \\
(\mathbf{n g} / \mathbf{m L})\end{array}$ \\
\hline Peanut 1 & $3.26 \pm 0.68^{\mathrm{a}}$ & $5.86 \pm 0.58^{\mathrm{a}}$ & + & $3.43 \pm 0.40^{\mathrm{a}, \mathrm{b}}$ \\
\hline Peanut 2 & $2.83 \pm 0.58^{\mathrm{a}}$ & $5.46 \pm 1.26^{\mathrm{a}}$ & + & $4.76 \pm 0.92^{\mathrm{a}}$ \\
\hline Peanut 3 & $2.50 \pm 0.10^{\mathrm{a}}$ & $6.20 \pm 0.45^{\mathrm{a}}$ & + & $2.36 \pm 0.90^{\mathrm{b}, \mathrm{c}}$ \\
\hline Flour 1 & $0.60 \pm 0.23^{\mathrm{b}}$ & $1.90 \pm 0.36^{\mathrm{c}}$ & + & $1.98 \pm 0.94^{\mathrm{b}, \mathrm{c}}$ \\
\hline Flour 2 & $0.44 \pm 0.22^{\mathrm{b}}$ & $1.83 \pm 0.35^{\mathrm{c}}$ & + & $3.33 \pm 0.51^{\mathrm{a}, \mathrm{b}}$ \\
\hline Flour 3 & $0.66 \pm 0.15^{\mathrm{b}}$ & $2.20 \pm 0.20^{\mathrm{c}}$ & + & $1.82 \pm 1.01^{\mathrm{c}}$ \\
\hline Milk-powder 1 & $0.93 \pm 0.71^{\mathrm{b}}$ & $2.90 \pm 0.70^{\mathrm{b}, \mathrm{c}}$ & + & $4.26 \pm 0.81^{\mathrm{a}}$ \\
\hline Milk-powder 2 & $0.82 \pm 0.50^{\mathrm{b}}$ & $3.83 \pm 0.55^{\mathrm{b}}$ & + & $1.55 \pm 0.67^{\mathrm{c}}$ \\
\hline Milk-powder 3 & $1.23 \pm 0.62^{\mathrm{b}}$ & $3.60 \pm 0.91^{\mathrm{b}}$ & + & $1.46 \pm 0.84^{\mathrm{c}}$ \\
\hline
\end{tabular}

The mean values indicated in the same column within variable with different superscripts $(a, b$, and $c)$ were significantly different $(p<0.05) ;+$ : present of fungal infection.

Although the correlation between the data in Figure 5A,B (comparing HPLC against VICAM and ELISA) reflected that the correlation of HPLC against VICAM (Figure 5A) was better than ELISA. On the other hand, a good correlation was observed between ELISA and VICAM (Figure 5C). However, the represented modified ELISA technique is easier to use, economic as it does not need sophisticated chemicals or highly trained technicians, have a good sensitivity to detect low infection levels determining aflatoxin B1 in foods and can represent a successful alternative in case other approaches are hard to be reached in less developed communities. Previous observations were reported for validation of a competitive direct SUNQuik ELISA for aflatoxin in peanuts using a reference HPLC method and other methods, including a minicolumn and the VICAM Afla test system [24]. The comparison between HPLC, VICAM, and validated method I-ELISA with respect to limit of detection, precision and accuracy, time of analysis, cost of analysis, and use of organic solvents is summarized in Table 4. 

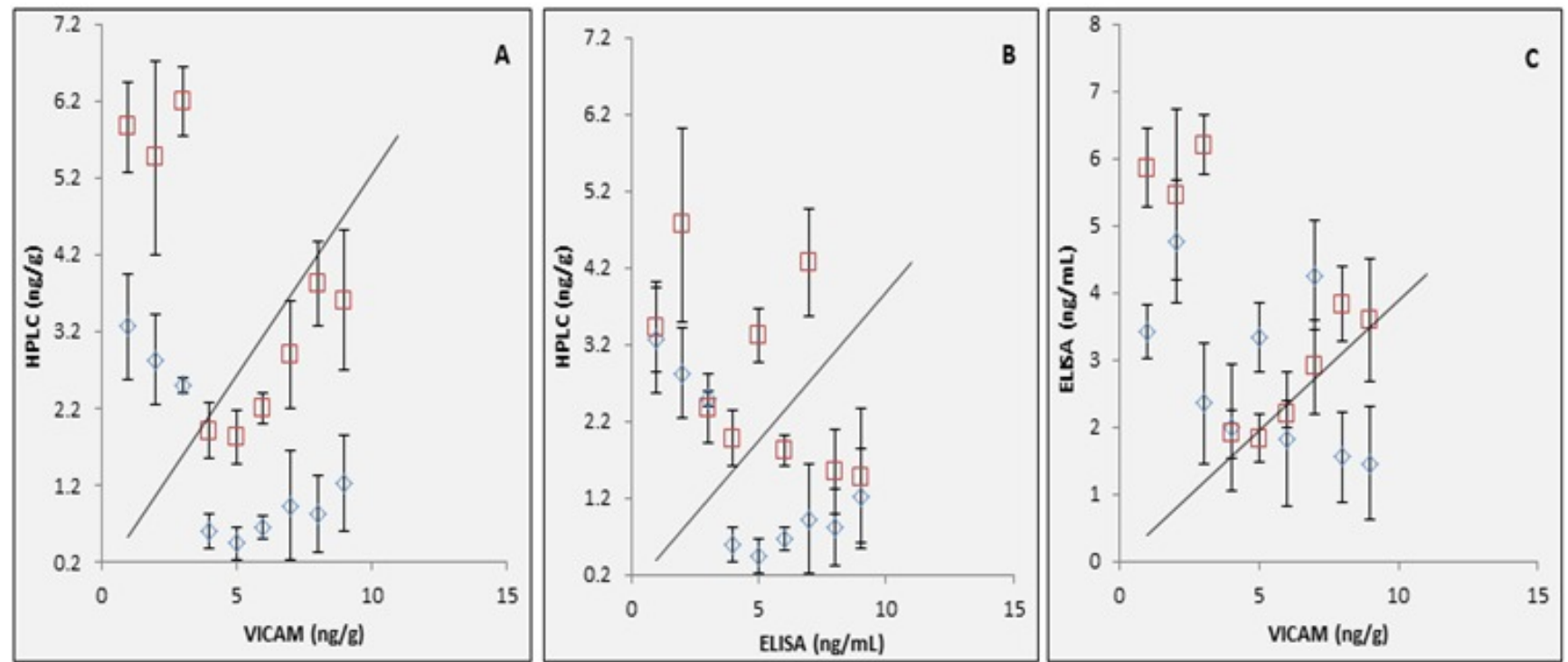

Figure 5. Correlations between HPLC and VICAM (A), HPLC and ELISA (B), ELISA and VICAM (C).

Table 4. Comparison between HPLC, VICAM, and validated method I-ELISA.

\begin{tabular}{cccc}
\hline Parameters & HPLC & VICAM & I-ELISA \\
\hline Limit of detection & $<0.008 \mathrm{ng} / \mathrm{mL}$ & $<2 \mathrm{ng} / \mathrm{mL}$ & $<1 \mathrm{ng} / \mathrm{mL}$ \\
\hline Time of analysis & $120 \mathrm{~min}$ & $90 \mathrm{~min}$ & $30 \mathrm{~min}$ \\
\hline Cost of analysis & High & Moderate & Moderate \\
\hline Use of organic solvents & Yes & Yes & No \\
\hline
\end{tabular}

\subsection{Limitations of the Modified Recombinant AflR Gene Antiserum ELISA Technique}

Our new established method has many limitations that must be clarified to determine and specify the application field of this method. First, our new ELISA technique does not measure the aflatoxins itself, hence, this type of test cannot be used for official control. However, it could be useful for auto control and rapid results and decision-making within a farm/company. Second, although this method is quantitative test, all positive results need to be confirmed with a confirmatory method such as HPLC or LC-MS as it is based on the measurement of a recombinant protein controlled by the gene responsible for aflatoxin biosynthesis, but not on the toxin itself.

\section{Conclusions and Future Perspective}

Aflatoxin B1 detection is an increasingly important health and economic issue. Accurate detection is essential to assess health problems in both humans and animals. Conventional detection methods are time-consuming and require expensive chemicals and apparatus (HPLC and VICAM). An accurate and rapid detection method that requires fewer chemicals is needed. We developed a specific quantitative detection technique (I-ELISA) using recombinant AflR protein. AflR is involved in aflatoxin biosynthesis. Comparison of results achieved from the new modified ELISA with other standardized methods HPLC and VICAM, revealed that the new ELISA technique can be used at many applications as an economic alternative to detect low levels of aflatoxin contamination. This modified technique may address problems associated with the reliable and rapid detection of aflatoxin B1 contamination in food products. The technique could be used to develop highly sensitive $(0-1000 \mathrm{pg} / \mathrm{mL})$ testing capabilities. In future, hybridoma cell culture antibody production technique can be used for production of antibodies against AfIR protein for large-scale manufacturing of rapid I-ELISA kit. This method will yield a production scale ranging from milligram to gram level with competitive pricing. 


\section{Materials and Methods \\ 4.1. Sampling}

Thirty-six food samples of three food products (12 samples each) were collected from a local market in Alexandria, Egypt. Products were prepared by different companies (4 packages each). Samples were peanuts (300 g packages), wheat flour (2 $\mathrm{kg}$ packages), and milk powder (500 g packages). Aflatoxin B1 was extracted for subsequent analysis.

\subsection{HPLC Detection}

One $\mathrm{mL}$ of each sample was centrifuged at $6000 \mathrm{rpm}$ for $15 \mathrm{~min}$, then filtered through a $0.45 \mu \mathrm{m}$ hydrophobic polytetrafluoroethylene syringe filter in preparation for gel pores chromatographic (GPC) analysis. The supernatant was transferred to $1.5 \mathrm{~mL}$ micro-tubes and passed through an immune-affinity column at a rate of 1-2 drops/s. The column was washed twice with $10 \mathrm{~mL}$ water: methanol (90:10) at a flow rate of $3 \mathrm{~mL} / \mathrm{min}$. Aflatoxins were eluted by slowly passing $1 \mathrm{~mL}$ of methanol through the column. The clear eluent was then repassed through a $0.45 \mu \mathrm{m}$ filter [25]. Subsequently, $100 \mu \mathrm{L}$ of trifluoracetic acid and $200 \mu \mathrm{L}$ n-hexane were added to samples and mixed by vortexing for $30 \mathrm{~s}$. The vial was left for $15 \mathrm{~min}$ before addition of $900 \mu \mathrm{L}$ of water: acetonitrile, 9:1 and remixing by vortexing. The hexane layer was then removed and samples were analyzed for AFs as previously reported [26] using a Waters HPLC system, Model 6000, a solvent delivery system, and a Model 720 system controller equipped with a fluorescence detector (Model 274) at excitation and emission wavelengths of 360 and $450 \mathrm{~nm}$, respectively. Separation used $5 \mu \mathrm{m}$ of sample, a Waters symmetry column $(150 \times 4.6 \mathrm{~mm}$ id), and a flow rate of $1 \mathrm{~mL} / \mathrm{min}$ with an isocratic system of $1 \%$ acetic acid: methanol: acetonitrile (55:35:10).

\subsection{AflA-Vt Detection}

Afla-V strip tests utilize the proven sensitivity and selectivity of VICAM monoclonal antibodies to accurately detect and measure aflatoxins B1 at levels of 2 to $100 \mathrm{ppb}$. These samples were subjected to aflatoxin extraction and quantification using the VICAM fluorometry method. Briefly, representative samples $(100 \mathrm{~g})$ of shelled peanuts were added with $10 \mathrm{~g}$ of $\mathrm{NaCl}$ and $200 \mathrm{~mL}$ of methanol/water $(80: 20 \mathrm{v} / \mathrm{v})$, homogenized using a Waring blender at high speed for $1 \mathrm{~min}$ and filtered through Whatman paper. Five $\mathrm{ml}$ of the filtrate was diluted with $20 \mathrm{~mL}$ HPLC water then re-filtered. Ten milliliter filtrate was purified with VICAM immunoaffinity columns (VICAM Aflatest, MA, USA) containing aflatoxin-specific (B1) monoclonal antibodies and washed with $10 \mathrm{~mL}$ HPLC water before the aflatoxin was eluted with $1 \mathrm{~mL}$ methanol. The eluted fraction was diluted twice with HPLC water and measured with the VICAM fluorometer (VICAM Series 4EX Fluorometer). All procedures were done according to the manufacturer's instructions [27].

\subsection{Specific PCR Detection Method}

DNA from food samples was extracted using a QiaGene DNA extraction kit (QiaGene, Berlin, Germany). DNA was dissolved in DEPC-treated water, quantified spectrophotometrically and analyzed using $1.2 \%$ agarose gels. The AflR gene (744 bp) was amplified using specific primers. The PCR reaction consisted of $1 \mu \mathrm{L}$ of DNA in $2.5 \mu \mathrm{L}$ Taq polymerase buffer $10 \times$ (Promega, New York, NY, USA) containing a final concentration of $1 \mathrm{mM} \mathrm{MgCl} 2,0.2 \mathrm{Mm}$ dNTPs, 20 pmol of each primer, and $0.2 \mu \mathrm{L}$ Taq polymerase $(5 \mathrm{U} / \mu \mathrm{L})$ in a final reaction volume of $25 \mu \mathrm{L}$. The PCR reaction program was: initial denaturation at $95{ }^{\circ} \mathrm{C}$ for two minutes followed by 35 cycles of $58^{\circ} \mathrm{C}$ for one min, $72{ }^{\circ} \mathrm{C}$ for one min, and $95{ }^{\circ} \mathrm{C}$ for $2 \mathrm{~min}$. A final extension step at $72{ }^{\circ} \mathrm{C}$ for $5 \mathrm{~min}$ was included at the end of the reactions. PCR amplification products were separated in $1.5 \%$ agarose with $0.5 \times$ TBE buffer and visually analyzed with a gel documentation system (Syngene) [28]. Forward (5'-TAAGCAGAATTCGAATAGCTTCGCAGGGTGGT-'3) and reverse (5‘-GAATAGCTTCGCAGGGTGGTGCGGCCGCTAAGCA-'3) primers were designed by Primer-Blast, NCBI. 


\subsection{Detection via AflR Gene Analysis and Transformation}

\subsubsection{Cloning, Sequencing, and AflR Gene Transformation}

The PCR product (Section 2.4) was excised from the gel and purified using a QIA quick gel extraction kit (Qiagen Inc., Berlin, Germany). Purified DNA was ligated into the pGEM-T vector (Promega Co., New York, NY, USA). Recombinant plasmids were directly sequenced using an automated sequencer (Macrogene Company, Seoul, Korea), with a universal vector primer. DNA homology searches were carried out using the NCB1 databases and the BLAST network service. EcoRI and NotI restriction enzymes were used for gene release and insertion into the pPROEX HTa expression vector (Life Technologies, New York, NY, USA). The recombinant plasmid was transformed into competent E. coli (BL21) cells and recombinant protein was recovered as previously described [29].

\subsubsection{Molecular Size Determination of AflR Recombinant Protein}

The recombinant protein was separated on $12 \%$ SDS PAGE and molecular size determined using a standard low range protein marker (BioRad, Hercules, CA, USA). Gel preparation, staining, and destaining were carried out following Laemmli [30].

\subsubsection{Epitope Prediction and Antigenic Determination}

B-cell epitope prediction analysis was performed following Kolaskar and Tongaonkar [16] to examine the epitope in different antigenic determinants.

\subsubsection{Immunization and Antibody Production}

Rabbit Immunization with AflR Recombinant Protein

Ten male New Zealand White rabbits, age 10-16 weeks and weighing 3.5-4.0 kg were used. Physical examinations confirmed lack of abnormalities. Rabbits were housed in stainless steel and polycarbonate cages (Techniplastic, West Chester, PA, USA), at $18-21^{\circ} \mathrm{C}$, with $30-70 \%$ humidity, and a 12-h: 12-h light: dark cycle (lights on at 0600). Rabbits were fed $250 \mathrm{~g}$ of a commercial pelleted rabbit diet (diet 2030, Harlan Laboratories, Madison, WI, USA) twice daily and were allowed free access to municipal water via an automatic watering system (Edstrom Industries, Waterford, WI, USA). After one-week of acclimatization, rabbits were divided into control ( 4 animals) and treated ( 6 animals) groups. The latter animals were injected subcutaneously with $500 \mu \mathrm{L}$ of purified protein $(2 \mathrm{mg} / \mathrm{mL})$ following the polyclonal antibody production protocol of Fishback et al. [31] with some modifications (Figure 6). The study was conducted after obtaining approval from the International Animal Care and Use Committees (IACUCs) IACUC \# 30-1Y-0521 (date of approval 10 January 2018).

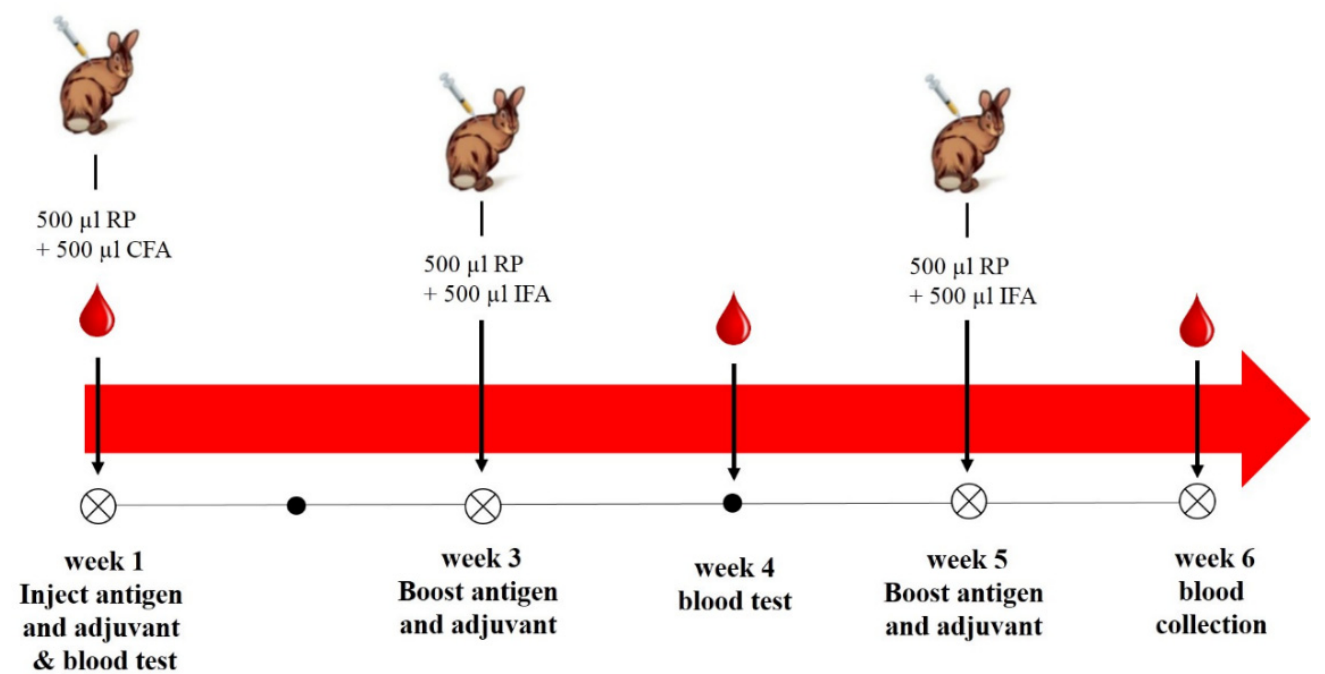

Figure 6. Polyclonal antibody production protocol. 
Three milliliter of blood was collected from the auricular artery of each rabbit on weeks 1 and 4 to monitor antibody production. On week 6 , under deep anesthesia with a mixture of $22-50 \mathrm{mg} / \mathrm{kg}$ ketamine and $5-10 \mathrm{mg} / \mathrm{kg}$ xylazine, $3 \mathrm{~mL}$ of blood was collected by cardiac puncture. Blood was collected into BD Vacutainer serum separation tubes (BD, Franklin Lakes, NJ, USA), and kept upright at room temperature $\left(20 \pm 2{ }^{\circ} \mathrm{C}\right)$ for serum separation following the manufacturer's instructions. Separated sera were stored at $-80{ }^{\circ} \mathrm{C}$ until further analysis.

Serum IgG Purification and Fractionation

Rabbit sera were obtained by centrifugation of immunized rabbit blood at $4000 \mathrm{rpm}$ for $5 \mathrm{~min}$ at $4{ }^{\circ} \mathrm{C}$. IgG fractions were obtained by loading sera onto an affinity Protein G-Sepharose column. In brief, the IgG1 fraction was eluted with glycine buffer, $\mathrm{pH}$ 2.7, and the IgG3 fraction obtained by elution with glycine buffer, $\mathrm{pH}$ 3.5. All IgG fractions were immediately neutralized in a neutralization buffer ( $1 \mathrm{M}$ Tris- $\mathrm{HCl}, \mathrm{pH}$ 8.0, $150 \mathrm{mM} \mathrm{NaCl}$, 5 mM EDTA) [32].

\section{Labelling of Antibodies}

Ten $\mathrm{mg}$ of alkaline phosphatase (AP) were mixed with purified IgGs $(2.5 \mathrm{mg})$ in $5 \mathrm{~mL}$ of $50 \mathrm{mM}$ phosphate buffer, $\mathrm{pH}$ 6.8. Mixtures were dialyzed against $2 \mathrm{~L}$ of $50 \mathrm{mM}$ phosphate buffer for $24 \mathrm{~h}$ at $4{ }^{\circ} \mathrm{C}$. One $\mathrm{mL}$ of $1.25 \%$ glutaraldehyde was added to each mixture and gently stirred for $2 \mathrm{~h}$ at room temperature $\left(20^{\circ} \mathrm{C} \pm 2\right)$. Two hundred fifty $\mu \mathrm{L}$ of $0.2 \mathrm{M}$ glycine solution was added followed by further stirring for $2 \mathrm{~h}$. Mixtures then were dialyzed twice against $2 \mathrm{~L}$ of $1.0 \times$ PBS containing $1 \mathrm{mM}$ magnesium chloride, followed by centrifugation at $10,000 \mathrm{rpm}$ for $5 \mathrm{~min}$ to remove any precipitate [33]. Each conjugate was further purified on a Sephacryl S200 column $(5 \times 150 \mathrm{~mm}$, GE Health care, Danderyd, Sweden) previously equilibrated with PBS and eluted with the same buffer.

\subsubsection{Quality Checks}

An indirect enzyme-linked immunosorbent assay (I-ELISA) was used to detect aflatoxin B1 in food samples using polyclonal antibodies. Antibodies were compared using an antiserum produced by Sigma (Berlin, Germany). One gram of contaminated food sample was extracted in $10 \mathrm{~mL}$ coating buffer. One hundred microliter of sample extract was added to each well. Plates were then incubated at $37^{\circ} \mathrm{C}$ for $3 \mathrm{~h}$ and blocked with $200 \mu \mathrm{L}$ of blocking buffer $(1 \times \mathrm{PBS}$ and $0.5 \% \mathrm{BSA})$ for $1 \mathrm{~h}$ at room temperature $\left(20^{\circ} \mathrm{C} \pm 2\right)$. One hundred microlite concentration of 1:800 diluted secondary antibody alkaline phosphataseconjugated (anti-rabbit antibody) was added and the mixture was incubated at $37^{\circ} \mathrm{C}$ for $1 \mathrm{~h}$. All washing steps between incubations used $1 \times$ PBS-T buffer. Finally, freshly prepared pNPP substrate was added; plates were incubated at room temperature for 30 min away from direct light, and the absorbance was measured at $405 \mathrm{~nm}$. All experimental steps are summarized in Figure 7. 


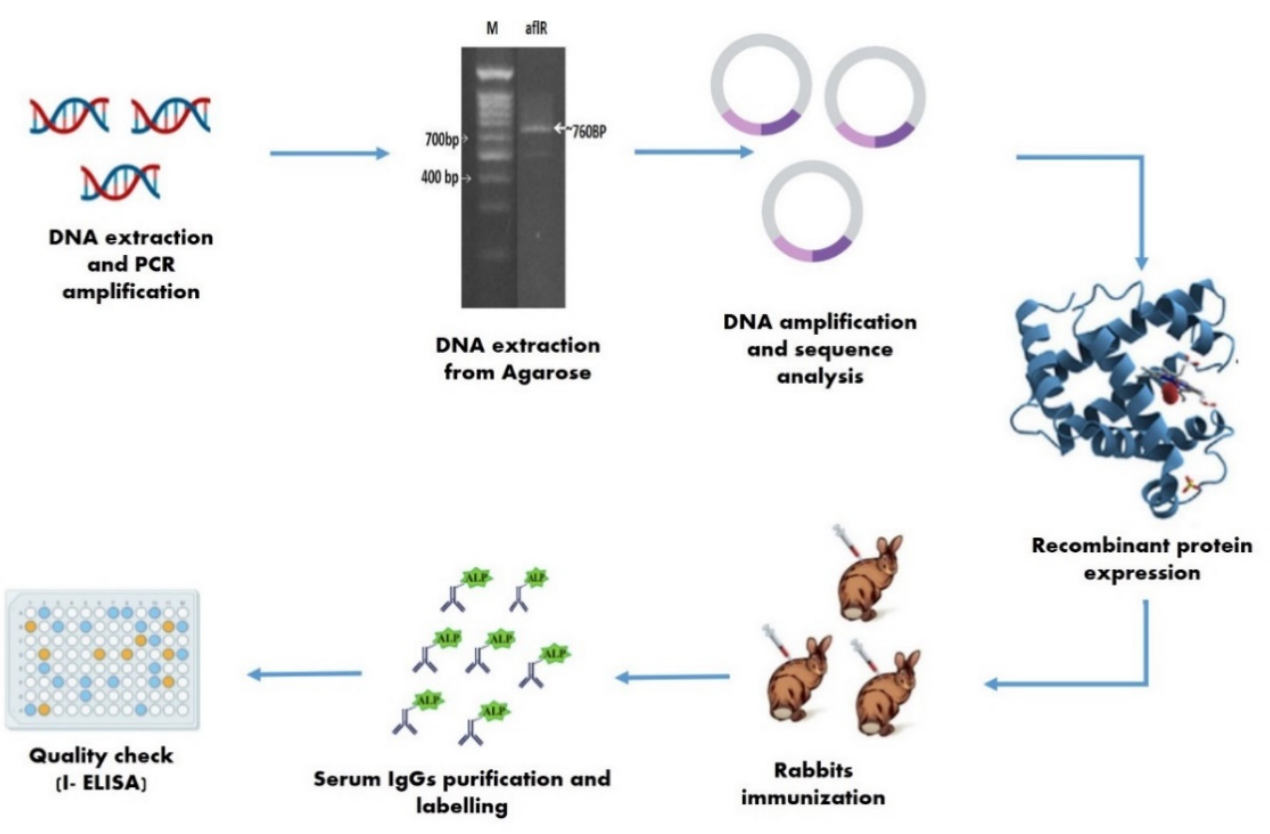

Figure 7. Summary of experimental steps.

\section{Statistical Analysis}

Data were statistically analyzed using SPSS software (version 16). One-way analysis of variance was used to assess the significance of differences among means, with a significance threshold of $p<0.05$. The Pearson correlation coefficient $(r)$ was also calculated $(p<0.001)$ to assess the strength of linear relationships between variables.

Author Contributions: Conceptualization, E.H., N.M.A.E.-A., A.M.G.D., M.G.S., A.A.I., A.M.E. and A.N.B.; methodology, E.H., N.M.A.E.-A., A.M.G.D., M.G.S., A.A.I. and A.M.E.; software and static analysis, E.H., N.M.A.E.-A., A.M.G.D., M.G.S., A.A.I., A.M.E. and A.N.B.; formal analysis, E.H., N.M.A.E.-A., A.M.G.D., M.G.S. and A.N.B.; investigation and data curation, E.H., N.M.A.E.-A., A.M.G.D., M.G.S. and A.N.B.; resources, E.H., N.M.A.E.-A., A.M.G.D. and M.G.S.; writing-original draft preparation, E.H., N.M.A.E.-A., A.M.G.D. and M.G.S.; writing-review and editing, E.H., N.M.A.E.-A., A.M.G.D., M.G.S., A.A.I., A.M.E. and A.N.B. All authors have read and agreed to the published version of the manuscript.

Funding: This research received no external funding.

Institutional Review Board Statement: Animal experiment was conducted upon the approval of International Animal Care and Use Committees (IACUCs) (Permission number: IACUC \# 30-1Y-0521, date of approval 10 January 2018).

Informed Consent Statement: Not applicable.

Conflicts of Interest: The authors declare no conflict of interest.

\section{References}

1. Goud, K.Y.; Reddy, K.K.; Satyanarayana, M.; Kummari, S.; Gobi, K.V. A review on recent developments in optical and electrochemical aptamer-based assays for mycotoxins using advanced nanomaterials. Microchim. Acta 2019, 187, 29. [CrossRef]

2. Hussain, K.K.; Malavia, D.; Johnson, E.M.; Littlechild, J.; Winlove, C.P.; Vollmer, F.; Gow, N.A.R. Biosensors and Diagnostics for Fungal Detection. J. Fungi 2020, 6, 349. [CrossRef] [PubMed]

3. Bryła, M.; Waśkiewicz, A.; Podolska, G.; Szymczyk, K.; Jędrzejczak, R.; Damaziak, K.; Sułek, A. Occurrence of 26 Mycotoxins in the Grain of Cereals Cultivated in Poland. Toxins 2016, 8, 160. [CrossRef] [PubMed]

4. Ezekiel, C.; Sulyok, M.; Babalola, D.; Warth, B.; Ezekiel, V.; Krska, R. Incidence and consumer awareness of toxigenic Aspergillus section Flavi and aflatoxin B1 in peanut cake from Nigeria. Food Control 2013, 30, 596-601. [CrossRef]

5. Dai, Y.; Huang, K.; Zhang, B.; Zhu, L.; Xu, W. Aflatoxin B1-induced epigenetic alterations: An overview. Food Chem. Toxicol. 2017, 109, 683-689. [CrossRef] [PubMed]

6. Payne, G.A.; Widstrom, N.W. Aflatoxin in maize. Crit. Rev. Plant Sci. 1992, 10, 423-440. [CrossRef] 
7. Shotwell, O.L.; Goulden, M.L.; Hesseltine, C.W. Aflatoxin: Distribution incontaminated corn. Cereal Chem. 1974, 51, 492-499.

8. Filazi, A.; Tansel, U. Occurrence of Aflatoxins in Food. Aflatoxins Recent Adv. Future Prospect. 2013, 143-170. [CrossRef]

9. Herzallah, S.M. Determination of aflatoxins in eggs, milk, meat and meat products using HPLC fluorescent and UV detectors. Food Chem. 2009, 114, 1141-1146. [CrossRef]

10. Wagner, K.; Springer, B.; Pires, V.P.; Keller, P.M. Molecular detection of fungal pathogens in clinical specimens by $18 \mathrm{~S}$ rDNA high-throughput screening in comparison to ITS PCR and culture. Sci. Rep. 2018, 8, 1-7. [CrossRef]

11. Gallo, A.; Stea, G.; Battilani, P.; Logrieco, A.F.; Perrone, G. Molecular characterization of Aspergillus flavus population isolated from maize during the first outbreak of aflatoxin contamination in Italy. Phytopathol. Mediterr. 2012, 51, 198-206. [CrossRef]

12. Alahi, M.E.E.; Mukhopadhyay, S.C. Detection methodologies for pathogen and toxins: A review. Sensors 2017, 17, 1885. [CrossRef]

13. Maggira, M.; Ioannidou, M.; Sakaridis, I.; Samouris, G. Determination of Aflatoxin M1 in Raw Milk Using an HPLC-FL Method in Comparison with Commercial ELISA Kits-Application in Raw Milk Samples from Various Regions of Greece. Vet. Sci. 2021, 8, 46. [CrossRef]

14. Vosough, M.; Bayat, M.; Salemi, A. Matrix-free analysis of aflatoxins in pistachio nuts using parallel factor modeling of liquid chromatography diode-array detection data. Anal. Chim. Acta 2010, 663, 11-18. [CrossRef] [PubMed]

15. Sapsford, K.; Ngundi, M.; Moore, M.; Lassman, M.; Shriver-Lake, L.; Taitt, C.; Ligler, F. Rapid detection of food-borne contaminants using an array biosensor. Sens. Actuators B Chem. 2006, 113, 599-607. [CrossRef]

16. Kolaskar, A.S.; Tongaonkar, P.C. A semi-empirical method for prediction of antigenic determinants on protein antigens. FEBS Lett. 1990, 276, 172-174. [CrossRef]

17. Schmidt, A.M. Development and application of synthetic peptides as vaccines. Biotechnol. Adv. 1989, 7, 187-213. [CrossRef]

18. Mahan, D.E.; Morrison, L.; Watson, L.; Haugneland, L.S. Phase change enzyme immunoassay. Anal. Biochem. 1987, 162, 163-170. [CrossRef]

19. Gruzdys, V.; Cahoon, K.; Pearson, L.; Lehman, C.M. Method Verification Shows a Negative Bias between 2 Procalcitonin Methods at Medical Decision Concentrations. J. Appl. Lab. Med. 2019, 4, 69-77. [CrossRef]

20. Harrison, B.D.; Barker, H.; Bock, K.R.; Guthrie, E.J.; Meredith, G.; Atkinson, M. Plant viruses with circular single-stranded DNA. Nat. Cell Biol. 1977, 270, 760-762. [CrossRef]

21. Padidam, M.; Beachy, R.N.; Fauquet, C.M. Classification and identific-ation of geminiviruses using sequence comparison. J. Gen. Virol. 1995, 76, 249-263. [CrossRef]

22. Abdel-Salam, A.M. Isolation and characterization of a whitefly-transmitted geminivirus associated with the leaf curl and mosaic symptoms on cotton in Egypt. Arab. J. Biotech. 1999, 2, 193-218.

23. Whitaker, T.B. Detecting Mycotoxins in Agricultural Commodities. Mol. Biotechnol. 2003, 23, 61-72. [CrossRef]

24. Lee, N.A.; Rachaputi, N.C.; Wright, G.C.; Krosch, S.; Norman, K.; Anderson, J.; Ambarwati, S.; Retnowati, I.; Dharmaputra, O.S.; Kennedy, I.R. Validation of analytical parameters of a competitive direct ELISA for aflatoxin B1in peanuts. Food Agric. Immunol. 2005, 16, 149-163. [CrossRef]

25. Lee, S.D.; Yu, I.S.; Jung, K.; Kim, Y.S. Incidence and Level of Aflatoxins Contamination in Medicinal Plants in Korea. Mycobiology 2014, 42, 339-345. [CrossRef]

26. Scaglioni, P.T.; Badiale-Furlong, E. Rice husk as an adsorbent: A new analytical approach to determine aflatoxins in milk. Talanta 2016, 152, 423-431. [CrossRef]

27. Ertekin, Ö.; Pirinçci, S..Ş.; Öztürk, S. Monoclonal IgA Antibodies for Aflatoxin Immunoassays. Toxins 2016, 8, 148. [CrossRef]

28. Saiki, R.K.; Gelfand, D.H.; Stoffel, S.; Scharf, S.J.; Higuchi, R.; Horn, G.T.; Mullis, K.B.; Erlich, H.A. Primer-directed enzymatic amplification of DNA with a thermostable DNA polymerase. Science 1988, 239, 487-491. [CrossRef] [PubMed]

29. Rosano, G.L.; Ceccarelli, E.A. Recombinant protein expression in Escherichia coli: Advances and challenges. Front. Microbiol. 2014, 5, 172. [CrossRef] [PubMed]

30. Laemmli, U.K. Cleavage of Structural Proteins during the Assembly of the Head of Bacteriophage T4. Nature 1970, 227, 680-685. [CrossRef] [PubMed]

31. Fishback, J.E.; Stronsky, S.M.; Green, C.A.; Bean, K.D.; Froude, J.W. Erratum: Antibody production in rabbits administered Freund's complete adjuvant and carprofen concurrently. Lab Anim. 2016, 45, 121. [CrossRef] [PubMed]

32. Gianazza, E.; Arnaud, P. A general method for fractionation of plasma proteins. Dye-ligand affinity chromatography on immobilized Cibacron blue F3-GA. Biochem. J. 1982, 201, 129-136. [CrossRef] [PubMed]

33. Avrameas, S. Coupling of enzymes to proteins with glutaraldehyde: Use of the conjugates for the detection of antigens and antibodies. Immunochemistry 1969, 6, 43-52. [CrossRef] 